\title{
Reptiles of the Hall Islands, Chuuk State, Federated States of Micronesia ${ }^{1}$
}

\author{
Donald W. Buden ${ }^{2}$
}

\begin{abstract}
Thirteen species of reptiles are recorded from the Hall Islands, all but two sea turtles for the first time. None of the 11 species of lizards (six geckos, five skinks) is endemic, and most are widely distributed throughout Micronesia and often well beyond. Emoia boettgeri has the most limited range, which extends from Chuuk State in the central Caroline Islands eastward to the Marshall Islands. Emoia caeruleocauda is the most common skink, and Lepidodactylus lugubris is the most common gecko. The apparent absence of other common Micronesian species, such as Nactus pelagicus, Emoia cyanura, E. impar, and Lipinia noctua is unexpected and possibly an artifact of limited sampling. A recent incident of turtle poisoning (chelonitoxism) attributed to the consumption of hawksbill turtle, Eretmochelys imbricata, resulted in the death of six Murilo Atoll islanders and sickened many others.
\end{abstract}

The вiота of the Hall Islands, Chuuk, Micronesia, has been incompletely surveyed. A remote location, long distances between islands, and unreliable or costly transportation impede travel to and among the islands and doubtlessly have contributed to the paucity of visiting biologists. This study was done largely to shed additional light on the distribution and relative abundance of reptiles; ancillary surveys of butterflies (Lepidoptera) and dragonflies (Odonata) will be reported elsewhere. With the exception of a few passing remarks on the status of sea turtles, the herpetofauna of these islands is largely unknown. The three island groups composing the Halls were visited over a period of 14 days during this study, but only seven of the more than 50 islands were visited. Given the dearth of previously available information, this study, limited sam-

\footnotetext{
${ }^{1}$ Manuscript accepted 4 January 2011.

${ }^{2}$ Division of Natural Sciences and Mathematics, College of Micronesia-FSM, P.O. Box 159, Kolonia, Pohnpei, Federated States of Micronesia 96941 (e-mail: don_ buden@comfsm.fm).
}

Pacific Science (2011), vol. 65, no. 4:497-505

doi: $10.2984 / 65.4 .497$

(C) 2011 by University of Hawai'i Press

All rights reserved pling notwithstanding, offers a first approximation of herpetofaunal diversity in the Hall Islands while acknowledging the need for additional and more extensive surveys to better assess the status and patterns of distribution of reptiles within this group of islands.

\section{Study Area}

The Hall Islands (East Fayu Island, Nomwin and Murilo Atolls) are a part of Chuuk State in the Federated States of Micronesia (FSM) in the west-central Pacific Ocean (Figure 1). The total land area of the more than 50 islets is $\sim 3.5 \mathrm{~km}^{2}$, and no island is larger than 0.42 $\mathrm{km}^{2}$ (Table 1). Nomwin and Murilo atolls are the emergent ends of a large twin-lobed seamount, each atoll having many predominately coconut (Cocos nucifera) forest-clad coralline islands and numerous smaller sparsely vegetated or barren sand cays distributed along the perimeter of a reef enclosing a large central lagoon. The main settlements are on Nomwin and Fananu islands on Nomwin Atoll, and Murilo and Ruo islands on Murilo Atoll. The 2000 national census recorded 711, 355, 607, and 469 residents at these four municipalities/islands, respectively (Division of Statistics 2002), but the population of the Hall Islands appears to have decreased in recent years. A few permanent 


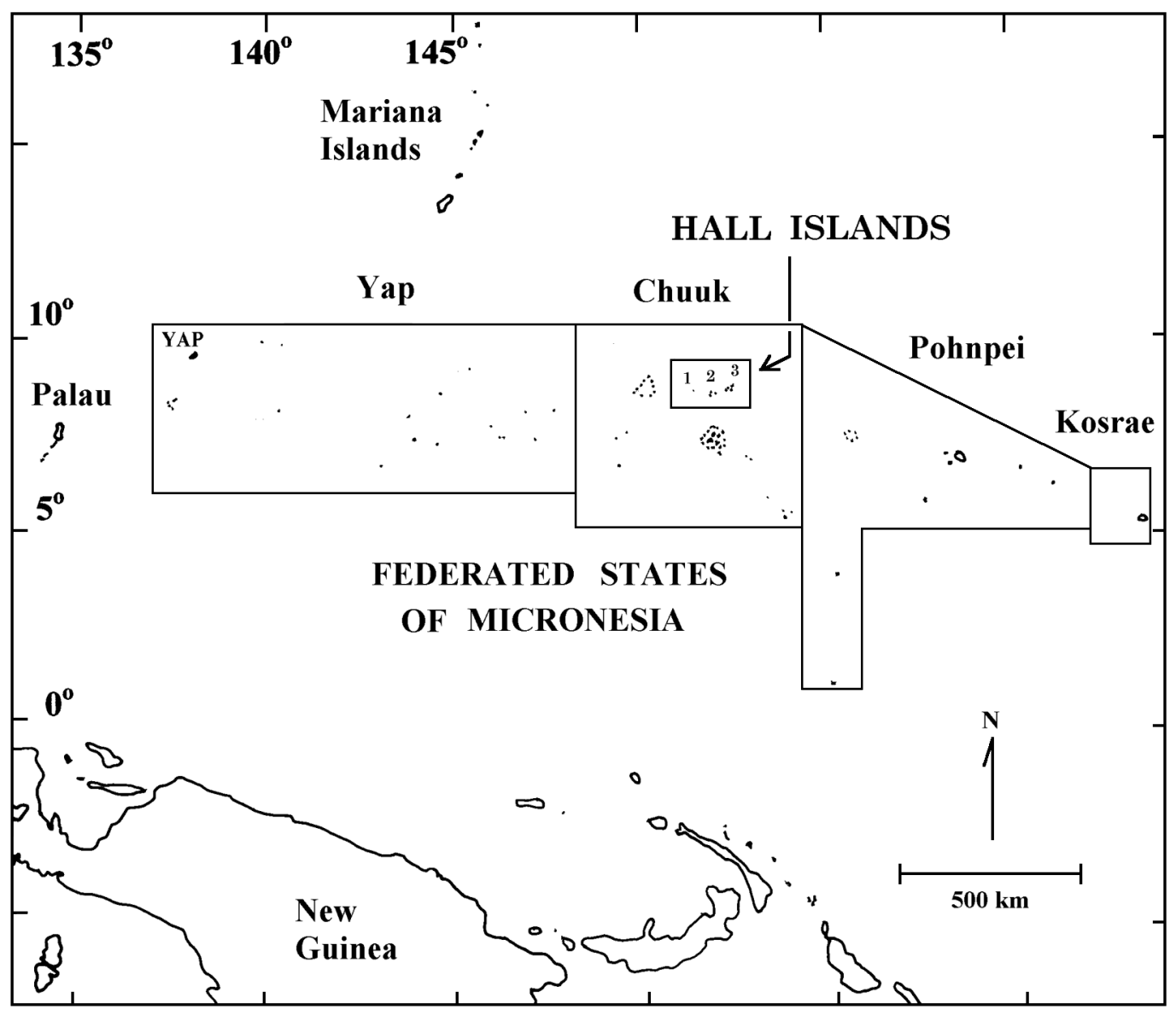

FIgURE 1. Location map for Hall Islands and surrounding islands: 1, East Fayu Island; 2, Nomwin Atoll; 3, Murilo Atoll.

TABLE 1

Statistical Data for the Hall Islands, Chuuk, Federated States of Micronesia

\begin{tabular}{|c|c|c|c|}
\hline Parameter & East Fayu Island & Nomwin Atoll & Murilo Atoll \\
\hline Coordinates $^{a}$ & $8^{\circ} 35^{\prime} \mathrm{N}, 151^{\circ} 22^{\prime} \mathrm{E}$ & $8^{\circ} 32^{\prime} \mathrm{N}, 151^{\circ} 47^{\prime} \mathrm{E}$ & $8^{\circ} 40^{\prime} \mathrm{N}, 152^{\circ} 11^{\prime} \mathrm{E}$ \\
\hline No. of islands ${ }^{a}$ & 1 & $28^{b}$ & $33^{b}$ \\
\hline Land area $\left(\mathrm{km}^{2}\right)^{a b}$ & 0.37 & 1.85 & 1.29 \\
\hline Lagoon area $\left(\mathrm{km}^{2}\right)^{a}$ & 0 & 291.44 & 349.73 \\
\hline Largest island $\left(\mathrm{km}^{2}\right)^{a}$ & 0.37 & 0.42 & 0.35 \\
\hline Population $^{c}$ & 0 & 1,066 & 1,076 \\
\hline Nearest land $(\mathrm{km})^{d}$ & 36.0 (Nomwin Atoll) & 9.0 (Murilo Atoll) & 9.0 (Nomwin Atoll) \\
\hline
\end{tabular}

${ }^{a}$ From Bryan (1971).

${ }^{b}$ Includes many unnamed and sparsely vegetated or completely barren sand cays.

' Based on the 2000 national census (Division of Statistics 2002).

${ }^{d}$ From the island encyclopedia, Oceandots.com (accessed at http://www.oceandots.com/pacific/caroline/nomwin.php). 
or semipermanent residences are scattered among some of the other islands, and all the islands are visited from time to time to collect crabs, coconuts, thatch, and other items that can be used by the islanders. East Fayu is a single, small, uninhabited coralline island that is currently divided into three vegetated segments connected by sand and gravel bars, and with a long, narrow bar extending $\sim 1.0 \mathrm{~km}$ beyond the vegetated segment at the south end. It is often visited by fisherman and turtle hunters from surrounding islands.

The highest elevations in the Halls are about $3-5 \mathrm{~m}$, with the highest areas often an accumulation of soil displaced during the excavation of pits for the cultivation of taro, mainly Cyrtosperma chamissonis. Breadfruit (Artocarpus spp.), often codominant with coconut on the larger islands, and taro (cultivated in large communal pits) are dietary staples throughout the region. Stone (1959) provided a more detailed description of the vegetation. The nearest high volcanic islands are in Chuuk Lagoon, $\sim 100 \mathrm{~km}$ south of Nomwin Atoll.

\section{MATERIALS AND METHODS}

Transportation to the Hall Islands from Weno, the administrative center of Chuuk, was by cargo ship, departing on 1 July 2010 and arriving at Fananu, Nomwin Atoll, on 2 July. Travel among the islands, and the return to Weno on 16 July, was on a small fishing boat equipped with a 40-horsepower (29.8 $\mathrm{kW}$ ) outboard motor. A total of 150 specimens of lizards was collected by hand, most of which were preserved in 10\% formalin, washed, and stored in 35\% isopropanol. Tissue samples of from one to several specimens each of the geckos Lepidodactylus spp. and Perochirus ateles and five species of skinks were preserved in ethanol for later DNA analysis. Although an effort was made to collect samples or record sightings of all species encountered on each of the islands visited, the number of specimens collected of each species does not necessarily reflect relative abundance; a disproportionate amount of time was spent in search of the less-common species. All the specimens of Lepidodactylus spp. and all tissue samples for DNA analysis, and the specimens from which they were taken, were sent to the U.S. Geological Survey San Diego Field Station, San Diego, California. The other specimens, currently stored at the national campus of the College of Micronesia, are expected to be distributed to the Bishop Museum, Honolulu; the California Academy of Sciences; the Museum of Comparative Zoology, Harvard University; and the National Museum of Natural History, Smithsonian Institution.

Terms of abundance are based on incidental observations and extrapolated to an estimated number of encounters per day with at least $6 \mathrm{hr}$ in the field: common (at least 30 sightings per day under optimum conditions), fairly common (usually $5-15$ per day), uncommon (1-5 on most days), scarce (fewer than 4 records). Carapace length in turtles was recorded as the straight line distance from the middle of the nuchal notch to the posteriormost edge of the shell.

\section{RESULTS}

\section{Turtles}

\section{Chelonia mydas (Linnaeus)}

I observed one green turtle tethered to a long rope on the beach at Fananu Island (Nomwin Atoll) and three others that were killed and being prepared for cooking on Murilo Island (Murilo Atoll), all during the first week of July 2010. The smallest was $40 \mathrm{~cm}$ in carapace length, and the others ranged from about 75 to $100 \mathrm{~cm}$ in length. During a brief stop at Namochis (= Numurus) Island at the southwestern tip of Murilo Atoll on the morning of 9 July, the boat pilot's son showed me two $C$. mydas hatchlings that he had just collected from among $\sim 50$ that he saw on the beach at Pissamwe Island, about 200-300 m from Namochis, on the other side of the reef. An adult male C. mydas captured by my "guides" on the reef at East Fayu on 10 July measured $101 \mathrm{~cm}$ in carapace length. It was killed and cooked on the beach. I saw several old tracks and nesting sites but no other turtles on land or in the water during my 3 days on East Fayu, 10-12 July. 


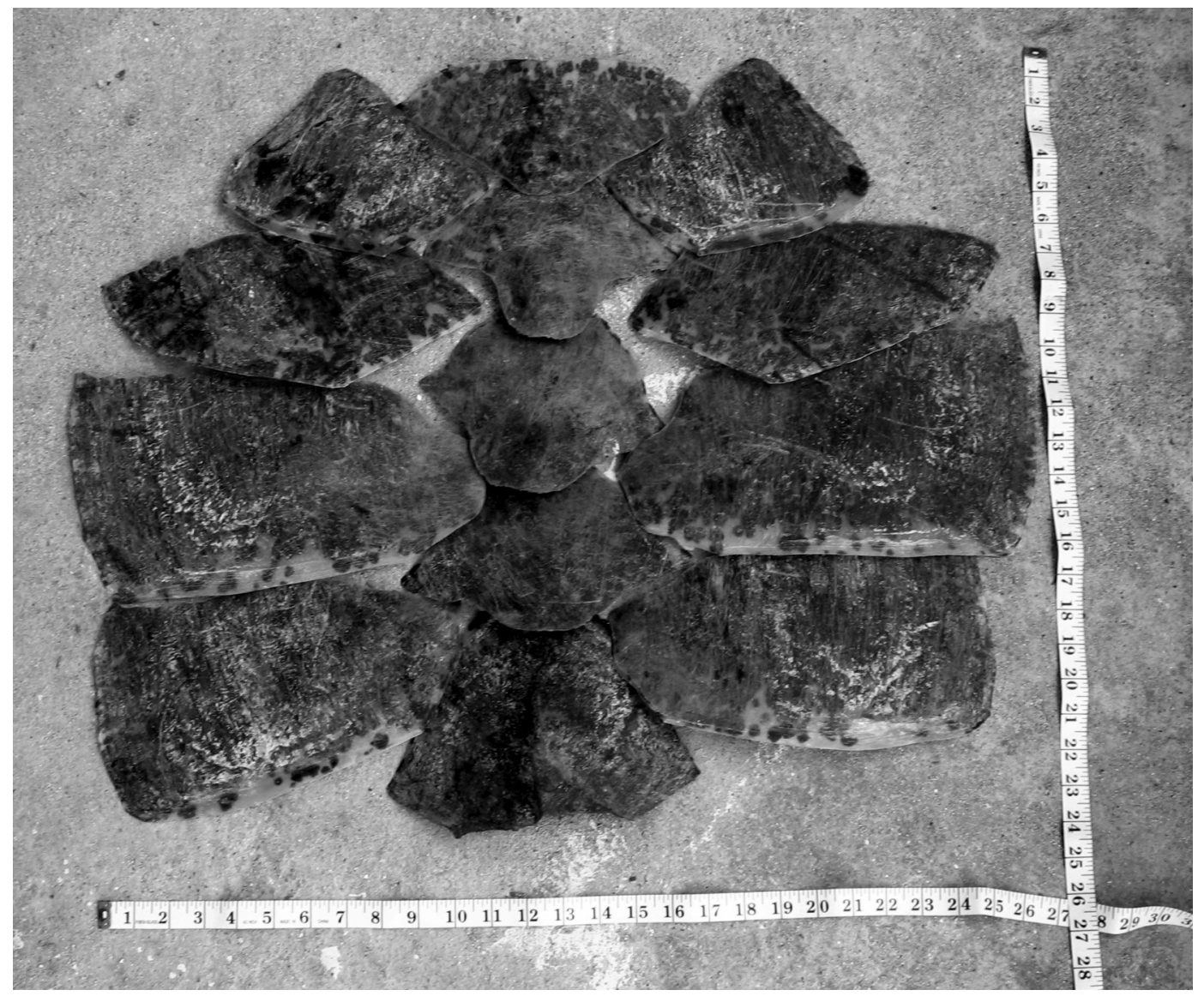

FIgURE 2. Scutes of hawksbill turtle implicated in chelonitoxism on Murilo Island, Murilo Atoll, October 2010; scale in inches (photograph courtesy of Dr. B. Pavlin).

Eretmochelys imbricata (Linnaeus)

I saw no hawksbill turtles in the Hall Islands, but many resident islanders (pers. comm.) indicated that it occurs throughout the region but is much less common than the green turtle. Krämer (1935) recorded Chelonia imbricata (=E. imbricata) in the Nomwin-Murilo atolls area during the 1908-1910 German South Seas Expedition, and Davis (1999) gave winichén and winichchen as alternative forms of the name used by Nomwin Atoll islanders for the hawksbill, and winimwén and winimwol for the green turtle. An incident of turtle poisoning (chelonitoxism) on Murilo Island during mid-October 2010 is attributed to consumption of a hawksbill turtle (B. Pavlin, pers. comm.); identification was confirmed via the scutes that were saved for making jewelry (Figure 2).

\section{Lizards}

Geckos:

Gebyra mutilata (Wiegmann)

The stump-toed or mutilating gecko was absent, scarce, or uncommon among the islands visited during this study. Of the four specimens (no others were seen), two were collected on walls of buildings in the settlement on Murilo Island, and two others on East Fayu, one in a palm leaf axil and the other on a tree trunk. 
Gebyra oceanica (Lesson)

The oceanic gecko was uncommon to fairly common on most of the islands visited and was encountered in a variety of habitats. Most of the sightings were at night in buildings, on tree trunks in the forest, and in scaevola shrubs along the beach. Others were encountered in palm leaf axils during the day.

\section{Hemidactylus frenatus (Duméril \& Bibron)}

The house gecko was abundant and the most frequently encountered gecko in edificarian habitats at night on Nomwin and Murilo islands. Of the 22 geckos randomly collected on the walls of buildings and other edifices on these two islands, $H$. frenatus accounted for 16 (73\%), followed by two each of Gebyra mutilata, G. oceanica, and Lepidodactylus sp. The house gecko probably occurs on populated islands elsewhere in the Halls group, including Ruo Island, Murilo (not visited), and Fananu Island, Nomwin (visited only briefly during midday).

\section{Lepidodactylus lugubris (Duméril \& Bibron)}

Twenty eight $(76 \%)$ of the 37 specimens of the genus Lepidodactylus collected in the Hall Islands were identified as L. lugubris based on external morphology, with some identifications to be confirmed by DNA studies later (R. Fisher, pers. comm.). This species appears to be common on all three island groups and occupies a wide range of habitats. Specimens were collected on tree trunks, in scaevola shrubs, in coral rubble along beaches, and on the walls of buildings, all at night, and under exfoliating bark of dead trees, under plant debris on the ground, and in palm leaf axils during the day.

\section{Lepidodactylus sp.}

Eight (22\%) of the 37 specimens of Lepidodactylus geckos collected in the Halls appear to be examples of an undescribed sexual species probably belonging to the same complex as the one encountered in Polynesia and the Marshall Islands (R. Fisher, pers. comm.; see also Ineich and Ota 1992 and Radtkey et al. 1995). Another is indeterminate lugubris or the sexual species.

\section{Perochirus ateles (Duméril)}

The Micronesian gecko was fairly common on the small and uninhabited islands of East Fayu and Pisef, but scarce on Murilo Island, where only one was collected and no others were seen. Whether its apparent absence on the other islands that were visited is real or an artifact of sampling (nighttime searches were brief or lacking) is uncertain. Six of the 12 specimens (Table 2) were collected in palm leaf axils during the day, five others from scaevola shrubs at night, and another on the side of a cement cistern shortly after sunrise.

\section{Skinks:}

\section{Emoia boettgeri (Sternfeld)}

The Boettger's skink was fairly common to very common on the forest floor and low on the tree trunks on most of the islands that were visited.

\section{Emoia caeruleocauda (De Vis)}

The Pacific blue-tailed skink was the most frequently encountered lizard in the Hall Islands during this study; with the estimated encounter rate being well over 100 per day on most of the islands that were visited. It was observed in all habitats but was most abundant on the forest floor and low on tree trunks, often occurring syntopically with $E$. boettgeri.

\section{Emoia jakati (Kopstein)}

The Jakati skink was fairly common to common in open sparsely vegetated areas and in leaf litter under scattered trees on nearly all the islands visited. It was most numerous in the vicinity of settlements and in coastal strand.

\section{Eugongylus albofasciolatus (Günther)}

The reclusive litter skink was observed regularly ( 1-2 sightings per day) on Nomwin and Murilo islands, and it probably occurs widely on other forested islands on both atolls. It was most frequently encountered in or near piles of accumulated plant debris and trash discarded by the islanders. Most of the sightings were in the vicinity of the settlements and usually during late afternoon. This species is almost certainly more common than the sightings indicate, but its crepuscular habits 
TABLE 2

Distribution of 150 Specimens and Sight Records (SR) of Lizards from Seven Islands ${ }^{a}$ in the Hall Islands, Chuuk, during 2-16 July 2010

\begin{tabular}{|c|c|c|c|c|c|c|c|}
\hline \multirow[b]{2}{*}{ Taxa } & \multirow[b]{2}{*}{ East Fayu } & \multicolumn{3}{|c|}{ Nomwin Atoll } & \multicolumn{3}{|c|}{ Murilo Atoll } \\
\hline & & Fan & Nom & Pis & Mur & Eor & Nam \\
\hline \multicolumn{8}{|l|}{ Geckos } \\
\hline Gebyra mutilata & 2 & & & & 2 & & \\
\hline G. oceanica & 4 & & SR & & 2 & 1 & \\
\hline Hemidactylus frenatus & & & 8 & & 8 & & \\
\hline Lepidodactylus lugubris & 6 & & 1 & 7 & 7 & 6 & \\
\hline Lepidodactylus sp. & & & & & 8 & 1 & \\
\hline Perochirus ateles & 5 & & & 6 & 1 & & \\
\hline \multicolumn{8}{|l|}{ Skinks } \\
\hline Emoia boettgeri & 6 & 1 & 3 & & 3 & 3 & \\
\hline E. caeruleocauda & 2 & 1 & 6 & & 5 & 5 & 5 \\
\hline E. jakati & 4 & 1 & 1 & & 2 & 2 & \\
\hline Eugongylus albofasciolatus & & & 3 & & 1 & & \\
\hline Lamprolepis smaragdina & 6 & 2 & SR & & 7 & 1 & 3 \\
\hline
\end{tabular}

${ }^{a}$ East Fayu Island $\left(0.37 \mathrm{~km}^{2} /\right.$ population $0 / \sim$ days on island, 3); Fan, Fananu Island $\left(0.34 \mathrm{~km}^{2} / 355 /<0.5\right)$; Nom, Nomwin Island $(0.40$ $\left.\mathrm{km}^{2} / 711 / 2\right)$; Pis, Pisef Island (0.06 km²/0/2); Mur, Murilo Island (0.14 km²/607/5); Eor Island (0.09 km²/0/2); Nam, Namochis (Numurus) Island $\left(0.16 \mathrm{~km}^{2} / \sim 5\right.$ [one family] $\left./<0.5\right)$.

and tendency to seek cover immediately when disturbed reduces the number of chance encounters in the field.

\section{Lamprolepis smaragdina (Lesson)}

The green tree skink was common on tree trunks on nearly all the islands visited but rarely encountered on the ground. It was most numerous on East Fayu, where 48 were counted over a period of $75 \mathrm{~min}(38.5 / \mathrm{hr})$. Dorsal coloration was recorded as dark brown or black in 38 (79.2\%), green in five others, and intermediate (brownish green, greenish brown, or yellowish brown) in another five. Coloration was not quantitatively assessed on the other islands, but incidental observations indicate that the dark brown or black morph predominates on Nomwin Island, whereas the population on Murilo Island is more variable, with proportionally more being green or intermediate in coloration.

\section{DISCUSSION}

Of the 13 species of reptiles recorded from the Hall Islands (two sea turtles, six geckos, five skinks), none is endemic and nearly all are widely distributed among the islands of the west-central Pacific. Emoia boettgeri has the most restricted range of the group, being known only from the central and eastern Caroline Islands and the Marshall Islands. Species commonly occurring in Micronesia but unrecorded in the Hall Islands include the gecko Nactus pelagicus and the skinks Emoia cyanura, E. impar, and Lipinia noctua. Whether these apparent absences are real or artifacts of limited sampling during this preliminary and incomplete survey is unknown. Many resident islanders (pers. comm.) remarked that the monitor lizard, Varanus indicus, which has a widespread but spotty distribution in Micronesia and was widely introduced to many of the atolls during the Japanese administration, is absent from the Hall Islands but occurs on Namonuito Atoll, $\sim 100 \mathrm{~km}$ to the west. The preponderance of presumptive L. lugubris within the Lepidodactylus sample from the Hall Islands (76\%), together with the absence of $L$. moestus, is in marked contrast to conditions encountered in some of the more western islands of the FSM, where, based on provisional identifications, L. moestus accounted for $65 \%$ (and L. lugubris 5\%) of 112 examples of the genus collected on Ngulu Atoll (Buden 2010) and $84 \%$ (with no L. lugubris) of 19 collected 
on Fais Island (Buden 2011). The relatively large number of L. lugubris and apparent absence or scarcity of L. moestus in the Halls more closely approximates the distribution pattern encountered in the eastern Carolines, where L. lugubris predominates and L. moestus is scarce or absent, as for example on Pohnpei (Buden 2000a) and Kapingamarangi Atoll (Buden 1998).

\section{Sea Turtles in the Hall Islands}

Pritchard (1977, 1982) stated that East Fayu was an important nesting site for green turtles, with about six to seven reported to nest each night beginning in February and continuing until about June, and that some nesting also takes place elsewhere in the Hall Islands on Fanang Island (Nomwin Atoll) and on some islands on Murilo Atoll. The East Fayu population apparently has since declined and was reported to be on the verge of extinction because of overharvesting for commercial and subsistence use (M. Nelson in $\mathrm{Na}$ tional Marine Fisheries Service and U.S. Fish and Wildlife Service 1998). The near absence of turtles during my 3-day visit to East Fayu in July may be indicative of a depleted population. Several Hall Islanders informed me that turtles were more common in the past than now and that many of those captured at East Fayu were being sold in Weno, the main population and administrative center of Chuuk. Stone (1959) reported that people from $\mathrm{Na}$ monuito Atoll traveled approximately $100 \mathrm{~km}$ to East Fayu from time to time because of the abundance of fish and turtles, and several Hall Islanders (pers. comm.) confirmed that $\mathrm{Na}$ monuito residents still visit for this resource.

Hawksbill turtles are less common than green turtles in the Hall Islands and elsewhere in Micronesia and are prized more for their scutes (for jewelry) than for their meat. During mid-October 2010, four children and two adults died and approximately 90 other people were sickened after consuming hawksbill turtle, or, in the case of nursing infants, breast milk from mothers who had eaten turtle (Federated States of Micronesia Department of Health and Social Affairs 2010; B. Pavlin, pers. comm.). Green turtles and hawksbills are eaten regularly on Murilo, and several other hawksbills in addition to the toxic specimen were consumed over the past year, but there is no previous history of turtle poisoning on the island (B. Pavlin, pers. comm.) Why the one turtle and none of the others was toxic is unknown.

The causative toxins of turtle poisoning (chelonitoxism) are not definitely known but are presumed to be acquired by the turtles from their diet (Aguirre et al. 2006, Fussy et al. 2007, U.S. Air Force 2008). However, lyngbyatoxin, derived from the widespread cyanobacterium Lyngbya majuscula, has been implicated in at least one death following consumption of turtle (Yasumoto 1998) and is strongly suspected to be at least one group of compounds contributing to other cases of chelonitoxism (e.g., Fussy et al. 2007, Gatti et al. 2008, Magnino et al. 2009).

Chelonitoxism is uncommon compared with other forms of seafood poisoning, and most of the reported incidents globally involve E. imbricata, although Chelonia mydas and (much less frequently) Dermochelys coriacea, and Caretta caretta have been implicated (Fussy et al. 2007). Records of chelonitoxism for the FSM are especially scanty, and the turtles that were identified in those cases were hawksbills (Buden 2000b). Regarding a more recent and previously unreported incident of chelonitoxism, Taylor Sehpin (pers. comm.) remarked on residents of Sapwuahfik Atoll, himself included, becoming ill after eating turtle in April 2010. Most of the afflicted were very young children and old people. Whether or not fatalities were involved in this incident was not definitely stated, and many other details are lacking, but the symptoms Sehpin and others experienced, including sore throat and difficulty in swallowing, are similar to those experienced by many of the Murilo Islanders. The turtle in the recent Sapwuakfik incident was unidentified but was described as having a shell in appearance somewhat between that of a green turtle and a hawksbill (T. Sehpin, pers. comm.).

The relatively small number of reported incidents of turtle poisoning worldwide, compared with other seafood poisonings, has been attributed to the geographically remote loca- 
tions of many victims, the absence of health care facilities, and the fear of reprisal in cases where consumption of turtle is contrary to custom, or where turtles are protected (Fussy et al. 2007). Brodin (1992) remarked on cultural restrictions on all species of turtles in Micronesia, but Buden and Edward (2001) pointed out that on Pohnpei turtles are hunted regularly and taken opportunistically, often with disregard to size limits, closed seasons, and other restrictions. A similar situation prevails in Chuuk but much less so in Yap, the most traditional of the FSM States (pers. obs.). Kosrae, the only state in the FSM lacking outlying atolls and lagoon islands, has no known breeding population of turtles. The few records of turtle poisoning from the FSM probably accurately reflect the sporadic and rare nature of chelonitoxism in this region. Although some cases may go unreported, turtles nevertheless are widely and regularly consumed on all the main islands, where medical facilities are readily available, and where incidents of poisoning, especially involving multiple members of a community, are very likely to become a part of local lore. Given the longstanding traditional and culturally rooted use of turtle as a food in Micronesia, and because this type of poisoning occurs rarely, the islanders likely will continue to consume turtle when it is available. While recognizing the inherent challenges in controlling turtle consumption, in the interest of public health, the Federated States of Micronesia Department of Health and Social Affairs (2010) has recommended a ban on consumption of turtles and their eggs (which can also be toxic), preferably to include all species in all of the FSM.

\section{ACKNOWLEDGMENTS}

I thank John Dungawain for arranging transportation in the Hall Islands, Mike Dungawain for use of his unoccupied house on Murilo Island, Pastor Mathias Sharisy and his wife Magdalena for providing food and lodging during my stay on Nomwin Island, and Mariano Mathias for piloting the boat used to travel among the Halls and for the return trip to Weno, Chuuk Lagoon. I thank Dr. Boris Pavlin for sharing the results of an epidemio- logical investigation of the incident of chelonitoxism on Murilo Atoll and for the illustration of the scutes of the toxic turtle, and Karen Arthur, George Balazs, and Ivan Ineich for providing literature on turtle poisoning. I also thank Robert N. Fisher for identifications of specimens of Lepidodactylus and for comments on a preliminary draft of the manuscript, and I am grateful for the courtesies extended by many resident islanders I met during my stay in the Halls.

\section{Literature Cited}

Aguirre, A. A., S. C. Gardner, J. C. Marsh, S. G. Delgado, C. J. Limpus, and W. J. Nichols. 2006. Hazards associated with the consumption of sea turtle meat and eggs: A review for health care workers and the general public. EcoHealth 3:141-153.

Brodin, S. 1992. Intoxication par consummation de tortue marine. Bull. Soc. Herp. Fr. 63:31-45.

Bryan, E. H., Jr. 1971. Guide to place names in the Trust Territory of the Pacific Islands. Pacific Science Information Center, Bishop Museum, Honolulu.

Buden, D. W. 1998. The reptiles of Kapingamarangi Atoll, Micronesia. Atoll Res. Bull. 453:1-8.

- 2000a. The reptiles of Pohnpei, Federated States of Micronesia. Micronesica 32:155-180.

- 2000b. The reptiles of Sapwuahfik Atoll, Federated States of Micronesia. Micronesica 32:245-256.

- 2010. Reptiles of Ngulu Atoll, Yap State, Federated States of Micronesia. Pac. Sci. 64:473-480.

- 2011. Reptiles of Fais Island, Yap State, Federated States of Micronesia. Pac. Sci. 65:277-283.

Buden, D. W., and A. Edward. 2001. Abundance and utilization of sea turtles on Pohnpei, Federated States of Micronesia: Islanders' perceptions. Micronesica 34:4754.

Davis, A. E. 1999. A preliminary list of animal names in the Chuuk District, with some notes on plant names. Micronesica 31:1215. 
Division of Statistics. 2002. FSM national detailed tables, 2000 FSM Census of Population and Housing, Department of Economic Affairs, FSM National Government, Palikir, Pohnpei.

Federated States of Micronesia Department of Health and Social Affairs. 2010. Turtle poisoning in Murilo Atoll, Chuuk State, Federated States of Micronesia (FSM). FSM DHSA, press release, November 2010. FSM National Government, Palikir, Pohnpei.

Fussy, A., P. Pommier, C. Lumbroso, and L. de Haro. 2007. Chelonitoxism: New case reports in French Polynesia and review of the literature. Toxicon 49:823-832.

Gatti, C., E. Oelher, and A. M. Legrand. 2008. Severe seafood poisoning in French Polynesia: A restrospective analysis of 129 medical files. Toxicon 51:746-753.

Ineich, I., and H. Ota. 1992. Additional remarks on the unisexual-bisexual complex of the gecko Lepidodactylus lugubris, in Takapoto Atoll, French Polynesia. Bull. Coll. Sci. Univ. Ryukyus 53:31-39.

Krämer, A. 1935. Inseln Um Truk (Centralkarolinen Ost). I. Halbband: LukunórInseln Und Námoluk; Lósap Und Nama; Lëmárafat, Namonuito Oder Onóun; Pollap-Támatam. In G. Thilenius, ed. Ergebnisse der Südsee-Expedition, 19081910. II. Ethnographie: B. Mikronesien, Band 6. Friederichsen, de Gruyter \& Co., Hamburg.
Magnino, S., P. Colin, E. Dei-Cas, M. Madsen, J. McLauchlin, K. Nökler, M. P. Maradona, E. Tsigarida, E. Vanopdenbosch, and C. Van Peteghem. 2009. Biological risks associated with consumption of reptile products. Int. J. Food Microbiol. 134:163-175.

National Marine Fisheries Service and U.S. Fish and Wildlife Service. 1998. Recovery plan for U.S. Pacific populations of the Green Turtle (Chelonia mydas). National Marine Fisheries Service, Silver Spring, Maryland.

Pritchard, P. C. H. 1977. Marine turtles of Micronesia. Chelonia Press, San Francisco. - 1982. Marine turtles of Micronesia. Pages 263-274 in K. M. Bjorndal, ed. Biology and conservation of sea turtles. Smithsonian Institution Press, Washington, D.C.

Radtkey, R. R., S. C. Donnellan, R. N. Fisher, C. Moritz, K. A. Hanley, and T. J. Case. 1995. When species collide: The origin and spread of an asexual species of gecko. Proc. R. Soc. Lond. B Biol. Sci. 259:145152.

Stone, B. C. 1959. The flora of Namonuito and the Hall Islands. Pac. Sci. 13:88-104.

U.S. Air Force. 2008. U.S. Air Force survival handbook. Skyhorse Publishing Inc., New York.

Yasumoto, T. 1998. Fish poisoning due to toxins of microalgal origins in the Pacific. Toxicon 36:1515-1518. 
